\title{
Growth arrest specific protein (GAS) 6: a role in the regulation of proliferation and functional capacity of the perinatal rat beta cell
}

\author{
T. N. Haase - M. Rasmussen - C. A. M. Jaksch • \\ L. W. Gaarn - C. K. Petersen • N. Billestrup • \\ J. H. Nielsen
}

Received: 28 August 2012 / Accepted: 13 December 2012 /Published online: 19 January 2013

(C) Springer-Verlag Berlin Heidelberg 2013

\begin{abstract}
Aims/hypothesis Maternal low-protein (LP) diet during gestation results in a reduced beta cell mass in the offspring at birth and this may hamper the ability to adapt to high-energy food and sedentary lifestyle later in life. To investigate the biology behind the LP-offspring phenotype, this study aimed to identify differentially expressed genes in the pancreas and their potential role in the fetal programming. Methods Wistar rats were given either an LP diet or normalchow (NC) diet during gestation and differentially expressed genes in the offspring around the time of birth were identified using RNA microarray and quantitative PCR. The role of a differentially expressed gene, growth arrest specific protein 6 (GAS6), was evaluated in vitro using neonatal rat islets.
\end{abstract}

Electronic supplementary material The online version of this article (doi:10.1007/s00125-012-2821-9) contains peer-reviewed but unedited supplementary material, which is available to authorised users.

T. N. Haase · M. Rasmussen • C. A. M. Jaksch • L. W. Gaarn •

C. K. Petersen $\cdot$ N. Billestrup $\cdot$ J. H. Nielsen $(\triangle)$

Department of Biomedical Sciences, Faculty of Health Sciences,

University of Copenhagen, Panum Institute, Blegdamsvej 3b,

Building 6.5,

2200 Copenhagen, Denmark

e-mail: jenshn@sund.ku.dk

\section{Rasmussen}

The Novo Nordisk Foundation Center for Basic Metabolic

Research, Faculty of Health Sciences, University of Copenhagen,

Copenhagen, Denmark

\section{W. Gaarn}

Thermo Fisher Scientific, Roskilde, Denmark
Results The mRNA level of Gas6, known to be mitogenic in other tissues, was reduced in LP offspring. The mRNA content of Mafa was increased in LP offspring suggesting an early maturation of beta cells. When applied in vitro, GAS6 increased proliferation of neonatal pancreatic beta cells, while reducing glucose-stimulated insulin secretion without changing the total insulin content of the islets. In addition, GAS6 decreased the mRNA content of Mafa.

Conclusions/interpretation We propose a role for GAS6 in the regulation of pancreatic beta cells in the critical period around the time of birth. Our results support the hypothesis that the reduced beta cell mass seen in LP offspring is caused by a change in the intra-uterine environment that favours premature maturation of the beta cells.

Keywords Fetal programming · Growth arrest specific protein 6 (GAS6) · Pancreatic beta cells
Abbreviations
EdU 5-Ethynyl-2'-deoxyuridine
GAS6 Growth arrest specific protein 6
GSIS Glucose-stimulated insulin secretion
HSA Human serum albumin
HBSS Hanks' balanced salt solution
hGH Human growth hormone
KRHB Krebs-Ringer HEPES buffer
LP Low protein
MAFA v-maf musculoaponeurotic fibrosarcoma oncogene homologue A
NC Normal chow
NGN3 Neurogenin 3
PDX1 Pancreatic duodenal homeobox-1
QPCR Quantitative real-time PCR 


\section{Introduction}

Maternal malnutrition during gestation, such as a low-protein (LP) diet, affects the intra-uterine environment and changes the programming of the fetus. This gives rise to an altered capacity to meet metabolic challenges later in life, when exposed to high-energy food and sedentary lifestyle, with an increased risk of developing metabolic diseases such as type 2 diabetes mellitus as a consequence. Accordingly, a correlation between a low birthweight and later development of insulin resistance and impaired glucose homeostasis is evident in humans as well as in animal studies [1-5].

The thrifty phenotype hypothesis suggests that the inadequate nutritional status of the fetus impairs the development of the endocrine pancreas with a reduced beta cell mass at birth as a consequence [2]. Indeed, human autopsy studies have shown that impaired synthesis and secretion of insulin in type 2 diabetes mellitus is associated with a reduced beta cell mass [6].

At the time around birth a dramatic increase in beta cell mass occurs $[7,8]$. The expansion arises from the proliferation of existing beta cells and by neogenesis from progenitor cells and declines after birth [9, 10].

A maternal LP-diet diminishes proliferation of the fetal beta cells around the time of birth [11, 12], and this could partly be caused by premature maturation at the expense of proliferation, thus giving rise to a reduced total beta cell mass [13]. Diet-induced changes in the temporal expression of transcription factors important for beta cell differentiation and maturation, such as v-maf musculoaponeurotic fibrosarcoma oncogene (MAF) homologue A and B and pancreatic duodenal homeobox-1 (PDX1), very likely play a role in development of the phenotype of LP offspring [14-16]. The regulation of these factors is, however, not fully clarified. Identification of factors regulating this process would give a clue to the treatment or prevention of the adverse effects of fetal programming of beta cells.

Growth arrest specific protein 6 (GAS6) is a vitamin K-dependent ligand for the AXL receptor tyrosine kinase subfamily [17]. It is secreted by endothelial cells and has been reported to have mitogenic and anti-apoptotic effects on several cell types, such as NIH 3 T3 fibroblasts, cardiac fibroblasts and hepatic cells [18-20] and to play a role in liver regeneration [21]. Gas6 mRNA is present in the pancreas [22] and synthesised by alpha cells of the islets of Langerhans [23]. A recent study reported an association between high plasma GAS6 concentrations and a decreased risk of developing of type 2 diabetes mellitus [24]. Additionally, a transgenic mouse strain possessing a constitutive active AXL receptor throughout cells of the myeloid haematopoietic linage, showed a non-insulin dependent diabetes mellitus phenotype with gradual age-dependent reduction in the number of insulin-positive cells, possibly due to sequestering of free GAS6-ligand present in plasma [25]. However, the possible role of GAS6 in regulation of beta cell mass or whether any receptors for GAS6 are present in beta cells has never been investigated.

The aim of this study was to investigate the role of GAS6 in regulation of proliferation, cell survival and functional capacity of pancreatic beta cells in isolated islets of Langerhans.

\section{Methods}

Animals

Experiments in this study were in accordance with the regulations of the Danish Animal Experimental Inspectorate. Animals were purchased from Taconic (Ry, Denmark).

\section{LP model}

Twenty-four Wistar rats (10-11 weeks old) were time-mated and transferred to local facilities. Twelve rats were assigned one of two isocaloric diets: LP ( $8 \%$ casein; Hope Farms 4400.00 , Woerden, Netherlands) or NC (20\% casein; Hope Farms 4400.01) (Table 1). Rats were pair-fed and allowed free access to water and kept under a $12 \mathrm{~h}$ light/12 h dark cycle until killed. Time-mated females were killed 2 days before giving birth (E20), immediately after giving birth (P0) or 2 days after giving birth (P2); offspring were decapitated and pancreases removed and placed directly in cold

Table 1 Composition of diets used in this study

\begin{tabular}{|c|c|c|}
\hline \multirow[t]{2}{*}{ Diet } & \multicolumn{2}{|c|}{ Content (g/kg diet) } \\
\hline & Normal protein & Low protein \\
\hline Standard vitamin mix 1 & 25 & 25 \\
\hline Standard trace element mix 1 & 25 & 25 \\
\hline $\mathrm{CaHPO}_{4} \cdot 2 \mathrm{H}_{2} \mathrm{O}$ & 6.5 & 11.5 \\
\hline Calcium carbonate & 15 & 11 \\
\hline $\mathrm{KH}_{2} \mathrm{PO}_{4}$ & 7 & 7 \\
\hline $\mathrm{KCl}$ & 7 & 7 \\
\hline $\mathrm{NaCl}$ (iodised) & 3 & 3 \\
\hline $\mathrm{MgSO}_{4} \cdot 7 \mathrm{H}_{2} \mathrm{O}$ & 4 & 4 \\
\hline $\mathrm{MgO}$ & 2 & 2 \\
\hline Methionine & 2 & 0.8 \\
\hline Choline chloride $(50 \%)$ & 4 & 4 \\
\hline Casein & 220 & 90 \\
\hline Corn starch & 80 & 80 \\
\hline Cellulose & 50 & 50 \\
\hline Soybean oil & 43 & 43 \\
\hline Cerelose/dextrose & 551.5 & 681.7 \\
\hline
\end{tabular}


TRI Reagent (Sigma-Aldrich, St Louis, MO, USA) for RNA extraction.

\section{Islet isolation}

Rats used for islet isolation were transferred to local facilities 1 day before the start of the experiments, kept under a $12 \mathrm{~h}$ light/ $12 \mathrm{~h}$ dark cycle until killed and allowed free access to food and water.

Neonatal rat islets were isolated from pancreases of 4-dayold Wistar rat pups [26]. Pups were killed by decapitation and pancreases were dissected and placed in ice-cold serum-free Hanks' balanced salt solution (HBSS; Lonza, Verviers, Belgium). Pancreases were distributed into tubes, and partially dissociated by use of collagenase (Roche, Penzberg, Germany) at a final concentration of $1.5 \mathrm{mg} / \mathrm{ml}$. Islets were isolated by use of Histopaque ( $1.077 \mathrm{~g} / \mathrm{ml}$ density) (Sigma, St Louis, MO, USA) for 20 min at 1,400g without brake. Islets were collected from the interface, washed with ice-cold HBSS containing 10\% FBS (Biosera, Ringmer, UK) and handpicked under a dissecting microscope.

Adult rat islets were isolated from 12-week-old male Wistar rats. Rats were killed and the pancreas was injected with Liberase TL Research Grade (Roche, Penzberg, Germany) at a final concentration of $0.2 \mathrm{mg} / \mathrm{ml}$ via the common bile duct. The pancreas was removed following injection of $6.5 \mathrm{ml}$ Liberase solution and incubated at $37^{\circ} \mathrm{C}$ for $21 \mathrm{~min}$. The suspension was passed through a metal filter (pore size $425 \mu \mathrm{m}$ ) and washed with cold HBSS containing 10\% FBS. Subsequently the islets were handpicked.

Rat islets were resuspended in RPMI 1640 with L-glutamine and $11 \mathrm{mmol} / 1$ glucose (Lonza) with 10\% FBS, $100 \mathrm{U} /$ $\mathrm{ml}$ penicillin and $100 \mathrm{U} / \mathrm{ml}$ streptomycin (Lonza), plated in bacteriological Petri dishes (Nunc, Roskilde, Denmark) and cultured at $37^{\circ} \mathrm{C}$ and $5 \% \mathrm{CO}_{2}$.

Human islets were provided through the JDRF Islet Distribution Program, which has been approved by central and local ethical committees. Islets were resuspended in RPMI 1640 (Lonza) with $5.6 \mathrm{mmol} / \mathrm{l}$ glucose, $10 \% \mathrm{FBS}, 100 \mathrm{U} / \mathrm{ml}$ penicillin and $100 \mathrm{U} / \mathrm{ml}$ streptomycin, plated in bacteriological Petri dishes and cultured at $37^{\circ} \mathrm{C}$ and $5 \% \mathrm{CO}_{2}$.

\section{Microarray analysis}

Microarray analysis was performed on whole pancreases from rat pups dissected out at three time points around birth for transcriptional profiling. Biotin-labelled cDNA was synthesised from $1 \mu \mathrm{g}$ perinatal pancreas total RNA according to the Affymetrix protocol (Affymetrix, Santa Clara, CA, USA) and hybridised to Rat Genome 2302.0 Array. Hybridisations and scanning were performed at Rigshospitalet Microarray Center (Copenhagen, Denmark). The statistical software package R v. 2.9.1 (http://www.r-project.org/) and
Bioconductor v. 2.5 (http://www.bioconductor.org/) was used to localise differentially expressed genes.

Quantitative real-time PCR

RNA from pancreas or isolated islets was extracted with TRI Reagent (Sigma-Aldrich) according to the manufacturer's instructions. The RNA content in the samples was measured on a NanoDrop ND1000 spectrophotometer (Nanodrop Technologies, Wilmington, DE, USA). cDNA was prepared by reverse transcription of RNA by use of qScript cDNA SuperMix (Quanta, Gaitherburg, MD, USA). A volume of each sample corresponding to $1 \mu \mathrm{g}$ RNA was used. Quantitative real-time PCR (qPCR) was performed on $10 \times$ diluted cDNA on Stratagene Mx 3000P (AH diagnostics, Aarhus, Denmark) using LightCycler FastStart DNA Master ${ }^{\text {PLUS }}$ SYBR Green I reaction mix (Roche, Mannheim, Germany). Samples were loaded in triplicates. Primers used in this study are given in electronic supplementary materials (ESM) Table 1.

For the in vitro studies with GAS6 for qPCR, islets were cultured for $48 \mathrm{~h}$ in RPMI 1640 (with L-glutamine and $11 \mathrm{mmol} / 1$ glucose) with $0.05 \%$ human serum albumin (HSA) (Sigma), $100 \mathrm{U} / \mathrm{ml}$ penicillin and $100 \mathrm{U} / \mathrm{ml}$ streptomycin treated with or without GAS6 $(300 \mathrm{ng} / \mathrm{ml})$ (catalogue No. 885-GS; R\&D Systems, Minneapolis, MN, USA).

\section{GSIS and insulin ELISA}

Islets were cultured for $96 \mathrm{~h}$ in RPMI 1640 (with L-glutamine and $11 \mathrm{mmol} / \mathrm{l}$ glucose) with $0.05 \% \mathrm{HSA}, 100 \mathrm{U} / \mathrm{ml}$ penicillin and $100 \mathrm{U} / \mathrm{ml}$ streptomycin treated with or without GAS6 $(300 \mathrm{ng} / \mathrm{ml})$. For assessment of insulin secretion 30 islets/ condition were pre-incubated for $90 \mathrm{~min}$ in Krebs-Ringer HEPES buffer (KRHB) supplemented with $2 \mathrm{mmol} / \mathrm{l}$ glucose in suspension culture plates (Sarstedt, Nümbrecht, Germany). Subsequently, the islets were transferred to fresh KRHB ( $2 \mathrm{mmol} / \mathrm{l}$ glucose), incubated for $30 \mathrm{~min}$ and then transferred to KRHB (20 mmol/l glucose) and incubated for $30 \mathrm{~min}$. The KRHB was collected for insulin measurements.

After GSIS experiments islets were re-collected, lysed (sonication: $40 \mathrm{~W}$ for $2 \times 15 \mathrm{~s}$ ) and saved for determination of insulin and DNA content.

Insulin levels in KRHB samples and total insulin content was determined by competitive ELISA using rat insulin as standard. The first antibody was rabbit polyclonal secondary antibody to guinea pig IgG, IgM and IgA (ab8522; Abcam, Cambridge, UK) and the second antibody was guinea pig anti-insulin (Novo Nordisk, Bagsværd, Denmark).

The total DNA content in the islets was determined using Quant-iT PicoGreen dsDNA Kit (Invitrogen, Paisley, UK) according to the manufacturer's instructions. 
Proliferation assay

Proliferation was quantified by 5-ethynyl-2'-deoxyuridine (EdU) incorporation in islets. Islets were cultured for $72 \mathrm{~h}$ in RPMI 1640 (with L-glutamine and $11 \mathrm{mmol} / 1$ glucose) containing $2 \%$ human serum (Lonza) in extracellular matrixcoated culture plates (Biological Industries, Kibbutz Beit Haemek, Israel). Islet were then cultured for $96 \mathrm{~h}$ in RPMI 1640 (with L-glutamine and $11 \mathrm{mmol} / 1$ glucose) with $0.05 \%$ $\mathrm{HSA}, 100 \mathrm{U} / \mathrm{ml}$ penicillin and $100 \mathrm{U} / \mathrm{ml}$ streptomycin treated with either GAS6 $(300 \mathrm{ng} / \mathrm{ml})$ or human growth hormone (Novo Nordisk; hGH, $400 \mathrm{ng} / \mathrm{ml}$ ) as a positive control. After $72 \mathrm{~h}$ of incubation EdU (Click-iT EdU imaging Kit; Invitrogen) was added $(10 \mu \mathrm{mol} / \mathrm{l})$ for $24 \mathrm{~h}$. The cultures were fixed in $4 \%$ formaldehyde and stained for PDX1 (BCBC antibody core, ab2027; Novo Nordisk) with Cy3-conjugated donkey anti-goat IgG as secondary antibody (705-166-147; Jackson Immunoresearch Laboratory, Suffolk, UK), for EdU and with Hoechst dye. Slides were assigned random numbers and counted blindly. Proliferation of beta cells was determined by counting one section (2D) from five islets per condition (approximately 800-1,800 cells) and calculating the fraction of cells positive for EdU (PDX1 ${ }^{+}$cells were counted using image J software (http://rsbweb.nih.gov/ij/); EdU ${ }^{+} \mathrm{PDX}^{+}$cells were counted manually) using a Zeiss LSM 710 Axio Imager confocal microscope (Zeiss, Jena, Germany).

\section{Apoptosis}

Apoptosis was measured by Cell Death Detection ELISA${ }^{\text {PLUS }}$ kit (Roche, Indianapolis, IN, USA) according to the manufacturer's instructions. Islets were cultured for $24 \mathrm{~h}$ in RPMI 1640 (with L-glutamine and $11 \mathrm{mmol} / 1$ glucose) with $0.05 \% \mathrm{HSA}, 100 \mathrm{U} / \mathrm{ml}$ penicillin and $100 \mathrm{U} / \mathrm{ml}$ streptomycin treated with GAS6 (300 ng/ml). After $24 \mathrm{~h}$, cytokines (recombinant mouse IL-1 $\beta$ [BD Pharmingen, San Diego, CA, USA] $150 \mathrm{pg} / \mathrm{ml}$, rat IFN- $\gamma$ [R\&D Systems] $0.1 \mathrm{ng} / \mathrm{ml}$ ) or palmitate $(1 \mathrm{mmol} / \mathrm{l})$ was added for $24 \mathrm{~h}$. After a total of $48 \mathrm{~h}$, apoptosis in cell lysates was measured by examination of the presence of cytoplasmic histone-associated DNA fragments.

Immunohistochemical staining

Perinatal and adult Wistar rat pancreases were fixed in $4 \%$ paraformaldehyde, and stored at $+4^{\circ} \mathrm{C}$ for 2 weeks. Next, pancreases were embedded in paraffin overnight and sliced into sections of $4 \mu \mathrm{m}$ and arranged on slides. Neonatal pancreases were cut in longitudinal slices and adult pancreas (caudal part) was cut in transverse slices. Sections were deparaffinised in xylene and hydrated with decreasing ethanol solutions in water. Specimens were stained using monoclonal rabbit anti-AXL IgG (LS-B7213; Life Span
Biosciences, Seattle, WA, USA) and monoclonal mouse anti-insulin IgG (ABM 816; Nordic Biosite, Copenhagen, Denmark) as primary antibodies and Alexa fluor 488 goat anti-rabbit (A11034; Invitrogen) and Alexa fluor 594 goat anti-mouse (A11005; Invitrogen) or goat peroxidaseconjugated anti-mouse (P0447; Dako, Glostrup, Denmark) as secondary antibodies, respectively. For fluorescence microscopy, specimens were mounted with Prolong Gold Antifade mounting media with DAPI (Invitrogen) and investigated with an Olympus BX43 fluorescence microscope (Olympus, Tokyo, Japan). Identical settings of the microscope were used when addressing stainings in neonatal and adult pancreas.

Measurement of endocrine pancreas

Two 4- $\mu \mathrm{m}$-thick longitudinal slices ( $>100 \mu \mathrm{m}$ distance) per neonatal rat pancreas (one to three pancreases per litter) were stained for insulin and counter-stained with haematoxylin and eosin. Using a $\times 10$ objective, pancreas sections were investigated with an Olympus BX43 microscope (Olympus, Tokyo, Japan), and five images/slice (covering $3.80 \pm 0.16 \mathrm{~mm}^{2}$ pancreas) were sampled. Slides were assigned random numbers and measured blindly. The islet area of total exocrine area (total area-total islet area) was measured with ImageJ software.

\section{Statistics}

Results are given as mean \pm SEM. mRNA levels in the LP study and effect of GAS6 on apoptosis was tested by a twoway ANOVA test. When a main effect was detected, a Student-Newman-Keuls post hoc test was performed to localise significant differences. The effects of the LP diet on offspring birthweight and size of the endocrine pancreas were tested by a one-tailed non-paired Student's $t$ test. The effects of GAS6 on mRNA, protein content and proliferation were tested by a two-tailed non-paired Student's $t$ test. The effect of GAS6 on insulin secretion was tested by a two-way repeated measurement ANOVA test. When a main effect was detected, a HolmSidak post hoc test was performed to localise significant differences. The significance level used is $p<0.05$.

\section{Results}

Maternal LP diet

Offspring from mothers fed an LP diet during gestation weighed $15 \%$ less $(p<0.05)$ at birth and tended $(p=0.065)$ to have $21 \%$ less pancreatic endocrine tissue relative to exocrine tissue than offspring from NC mothers (Fig. 1a, b) in accordance with data from previous studies $[12,13]$. The microarray analysis of the transcriptome from rat pup pancreases revealed several genes as being differentially 

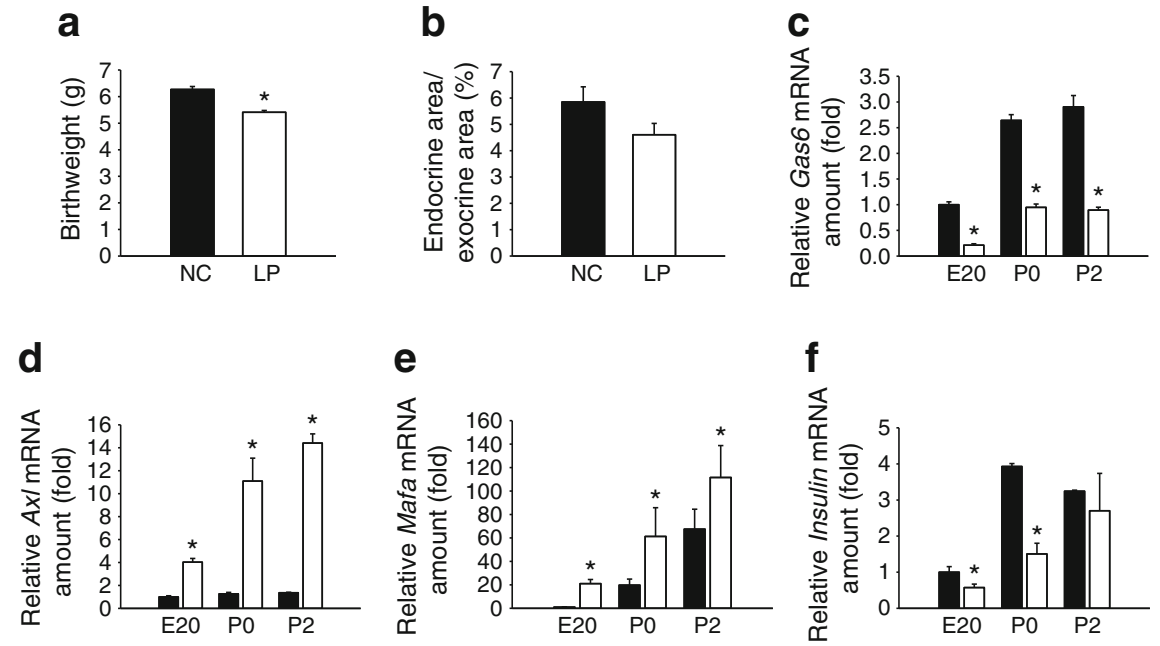

Fig. 1 Effects of a maternal LP diet on offspring in Wistar rats. Birthweight (a) and \% of islet area of total exocrine area of the pancreas of pups at birth (b) from rats given an NC or an LP diet during gestation ( $n=3-5)$. (c-f) Quantification of the Gas6, Axl, Mafa and insulin mRNA content in pancreases from NC (black bar) and
LP (white bar) offspring 2 days before birth (E20), immediately after birth (P0) and 2 days after birth (P2). Results are normalised to the mRNA content of $R p l 13 \alpha$ and expressed as fold change compared with $\mathrm{NC}$ at E20 ( $n=2$ or 3$)$. Data shown as mean \pm SEM. ${ }^{*} p<0.05$ compared with $\mathrm{NC}$ expressed. Results from the microarray study will be described in detail elsewhere (M. Rasmussen, L. W. Gaarn, T. N. Haase, J. H. Nielsen, unpublished results). The expression of selected genes was investigated by qPCR (Fig. 1c-f). Gas6 mRNA content was reduced $63-75 \%(p<0.05)$ at all time points in offspring from LP mothers compared with offspring from NC mothers. Axl mRNA content was increased four- to eightfold $(p<0.05)$ at all time points in offspring from LP mothers. Mafa mRNA content was increased 21-fold ( $p<$ $0.05)$ at E20, threefold $(p<0.05)$ at $\mathrm{P} 0$ and $65 \%(p<0.05)$ at $\mathrm{P} 2$ in offspring from LP mothers. The insulin mRNA content was reduced $40 \%(p<0.05)$ at E20, 60\% $(p<0.05)$ at $\mathrm{P} 0$ and was similar at P2 in offspring from LP mothers.

\section{Effect of GAS6 on neonatal rat beta cells in vitro}

To investigate the effect of GAS6 on neonatal rat beta cells, isolated islets were cultured with recombinant GAS6 and the effects on GSIS, mRNA content, proliferation and apoptosis was examined.

GSIS and insulin content The basal level of insulin secretion in response to $2 \mathrm{mmol} / \mathrm{l}$ glucose was similar in neonatal rat islets cultured with or without GAS6 (Fig. 2a). When stimulated with $20 \mathrm{mmol} / \mathrm{l}$ glucose islets cultured with or without GAS6 increased their level of insulin secretion tenfold and ninefold, respectively. However, the amount of insulin secreted in response to $20 \mathrm{mmol} / 1$ glucose by islets cultured with GAS6 was $25 \%$ lower $(p<0.05)$ than by the amount secreted by islets cultured without GAS6. The total insulin content of islets was not affected by GAS6 (Fig. 2b). $m R N A$ content Mafa mRNA content was $70 \%$ reduced $(p<$ $0.05)$ in islets cultured with GAS6 as compared with control (Fig. 3a). The mRNA content of $A x l$ was also $70 \%$ reduced $(p<0.05)$ in islets cultured with GAS6 (Fig. 3b). There was no effect of GAS6 on the mRNA content of $P d x 1$ or insulin (Fig. 3c, d) or Mafb, Ngn3 (also known as Neurog3) and Gas6 (data not shown).

Proliferation Neonatal rat beta cells $\left(\mathrm{PDX}^{+}\right.$cells) cultured with GAS6 increased their incorporation of EdU 30\% $(p<$ 0.05 ) compared with control (Fig. 4). hGH increased the proliferation of beta cells $\sim 105 \%(p<0.05)$ compared with control.
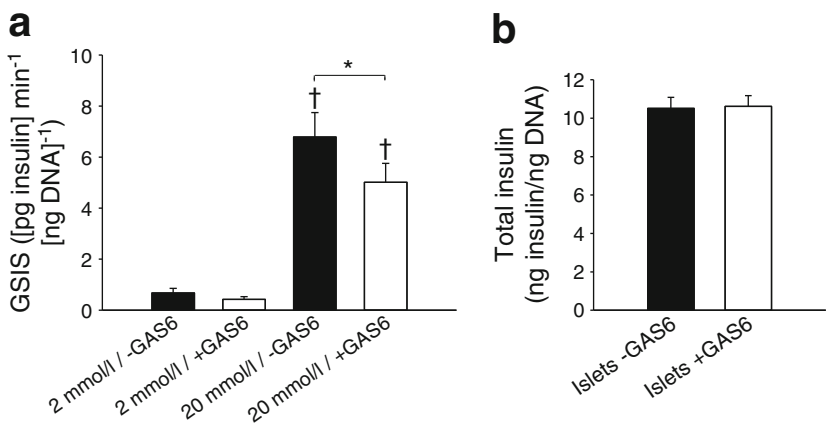

Fig. 2 GSIS and quantification of total insulin protein content in neonatal rat islets cultured with or without GAS6 (+GAS6, $300 \mathrm{ng} / \mathrm{ml}$; -GAS6) for $96 \mathrm{~h}$. (a) GSIS using $2 \mathrm{mmol} / 1$ glucose and $20 \mathrm{mmol} / 1$ glucose. (b) Total insulin content. Data are shown as means \pm SEM, $n=6 .{ }^{\dagger} p<0.05$ compared with $2 \mathrm{mmol} / \mathrm{l}$ glucose within -GAS6 and +GAS6. ${ }^{*} p<0.05$ compared with -GAS6 within $20 \mathrm{mmol} / \mathrm{l}$ 

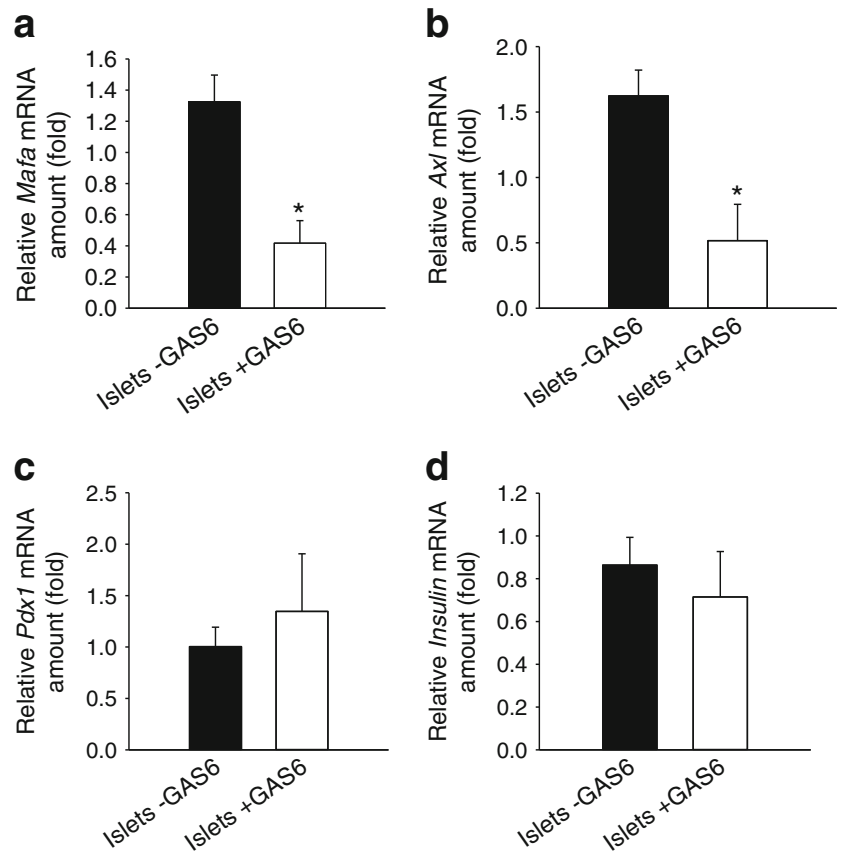

Fig. 3 Quantification of mRNA content of Mafa (a), Axl (b), $P d x l$ (c) and insulin (d) by qPCR in neonatal rat islets treated with or without GAS6 (+GAS6, $300 \mathrm{ng} / \mathrm{ml}$; -GAS6) for $48 \mathrm{~h}$. Results are normalised to the mRNA content of Rpl13 $\alpha$. Data shown as means \pm SEM, $n=5$. ${ }^{*} p<0.05$ compared with - GAS6

Cytokine- and palmitate-induced apoptosis In response to IL-1 and IFN- $\gamma$ the level of apoptosis increased 2.5- to threefold in control and GAS6-treated neonatal rat islets (Fig. 5a). Palmitate increased the level of apoptosis 2.5-fold in both treatment groups (Fig. 5b). GAS6 did not affect the cytokine or palmitate-induced level of apoptosis.
Effect of GAS6 on adult rat beta cells in vitro

To determine whether the identified effects of GAS6 in vitro on rat islets was age dependent, similar experiments were conducted on islets isolated from adult rats.

GSIS, total insulin and mRNA content The basal insulin secretion in response to $2 \mathrm{mmol} / \mathrm{l}$ glucose was similar in adult rat islets cultured with or without GAS6 (Fig. 6a). Increasing the glucose concentration to $20 \mathrm{mmol} / \mathrm{l}$ glucose induced a 16-fold increase in insulin secretion in both control and GAS6-treated islets. There was no difference in insulin secretion between control and GAS6-treated islets at either $2 \mathrm{mmol} / \mathrm{l}$ or $20 \mathrm{mmol} / \mathrm{l}$ glucose. The total insulin content of the islets was not affected by GAS6 (Fig. 6b).

Neither Mafa nor Axl mRNA content in adult rat islets was affected by GAS6 (Fig. 6c, d).

Proliferation Adult rat beta cells cultured with GAS6 showed no statistically significant increase in proliferation compared with control (Fig. 7). hGH increased proliferation of beta cells fourfold $(p<0.05)$ compared with control.

\section{AXL in rat pancreas}

To investigate whether the AXL receptor tyrosine kinase is expressed in beta cells, histological sections of neonatal and adult rat pancreas were immunohistochemically stained.

Numerous beta cells (insulin ${ }^{+}$cells) in the islets of Langerhans were positive for AXL in the neonatal pancreas (Fig. 8a). A weaker presence of AXL was seen in cells of the exocrine tissue. In accordance with this, the level of $A x l$
Fig. 4 Effect of GAS6 on proliferation of neonatal rat islets. Representative sections (a) of neonatal rat islets cultured for $96 \mathrm{~h}$ as control, with hGH (positive control) or with GAS6 (300 ng/ml). Islets were cultured with EdU $24 \mathrm{~h}$ before fixation, and subsequently stained for PDX1. Red bar indicates $50 \mu \mathrm{m}$. (b) Quantification of the percentage of $\mathrm{EdU}^{+} \mathrm{PDX} 1^{+}$cells (positive for EdU and PDX1) of total $\mathrm{PDX}^{+}$cells (\%). Data are shown as means \pm SEM, $n=5$ or 6. ${ }^{*} p<0.05$ compared with control. ${ }^{\dagger} p<0.05$ compared with hGH a
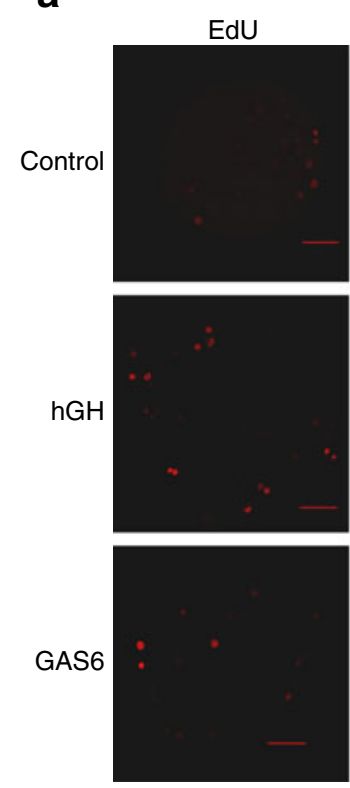
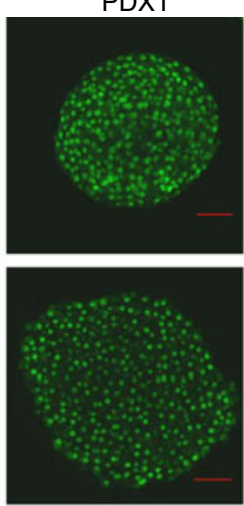

b
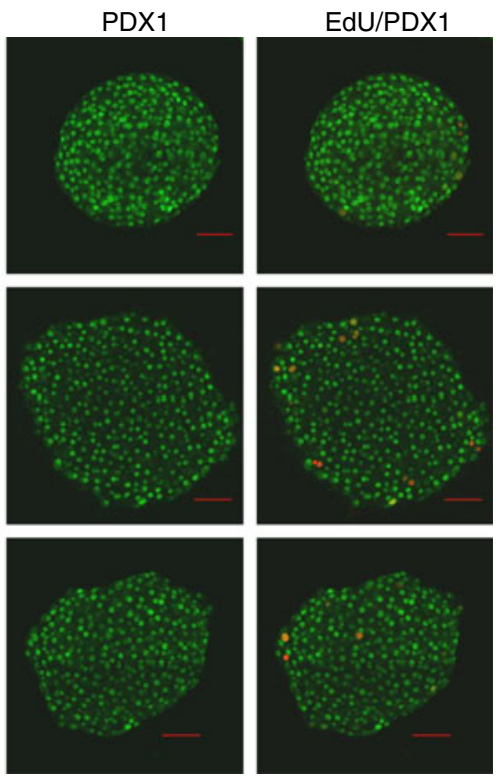

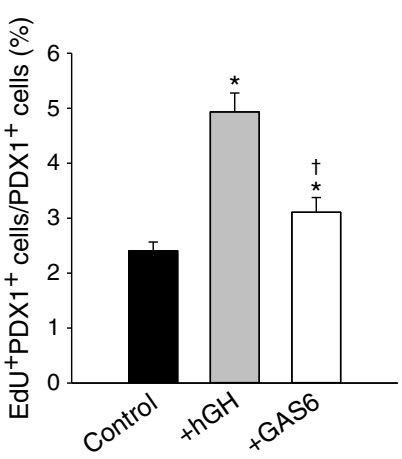



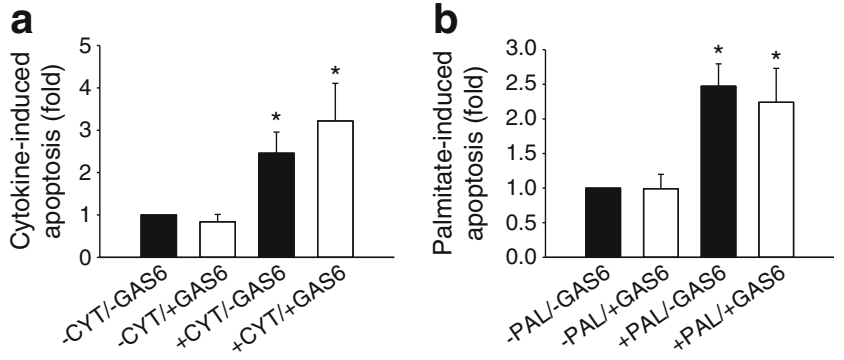

Fig. 5 Cytokine- (a) and palmitate-induced (b) apoptosis of neonatal rat islets cultured with or without GAS6 (+GAS6, $300 \mathrm{ng} / \mathrm{ml}$; -GAS6) for $48 \mathrm{~h}$ quantified by use of Cell Death Detection ELISA ${ }^{\text {PLUS }}$. After $24 \mathrm{~h}$, cytokines (CYT; IL-1 $150 \mathrm{pg} / \mathrm{ml}$, IFN- $\gamma 0.1 \mathrm{ng} / \mathrm{ml}$ ) or palmitate (PAL, $1 \mathrm{mmol} / \mathrm{l}$ ) were added to the culture medium. Results are expressed as fold change compared to $-\mathrm{CYT} /-$ Gas6 and -PAL/-Gas6, respectively. ${ }^{*} p<0.05$ compared with no cytokines or palmitate $(-\mathrm{CYT} /-\mathrm{PAL})$. Data are shown as means \pm SEM, $n=6$

mRNA in neonatal islets constituted $32 \%$ of the total pancreatic content of $A x l$ mRNA (Fig. 8b) (when the endocrine pancreas was estimated to cover $5.85 \%$ of the total pancreas, i.e. Fig. 1b). Alpha cells (glucagon $^{+}$cells) also expressed AXL (data not shown).

In adult pancreas some beta cells were positive for AXL. The presence of AXL in the exocrine tissue was scarce compared to the neonatal pancreas. The majority of alpha
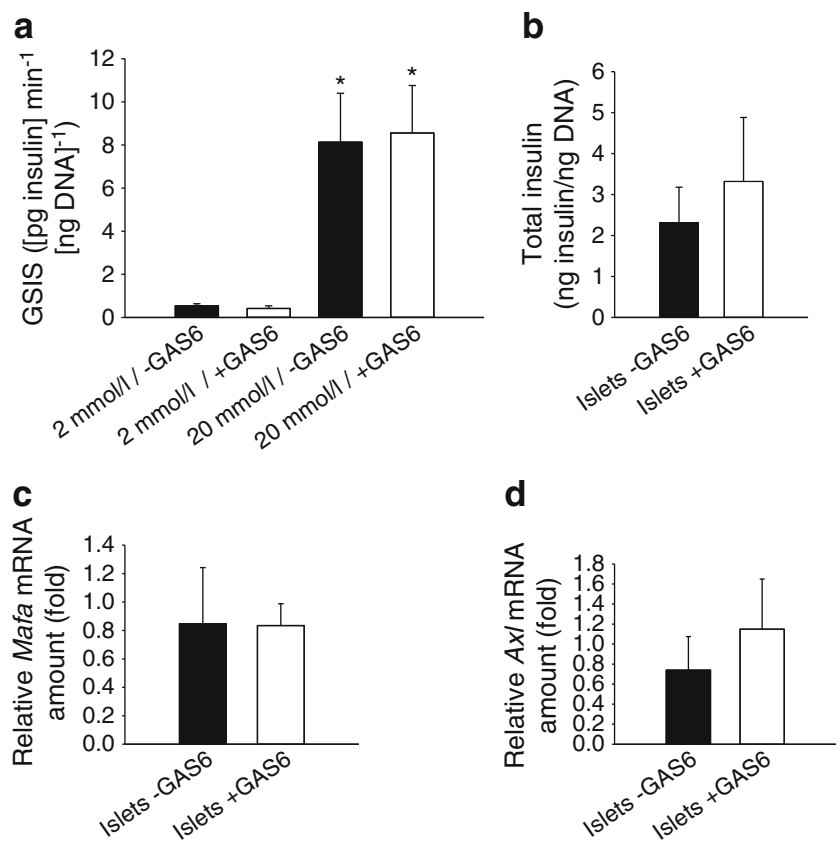

Fig. 6 GSIS using $2 \mathrm{mmol} / \mathrm{l}$ glucose and $20 \mathrm{mmol} / \mathrm{l}$ glucose (a) and quantification of total insulin protein content $(\mathbf{b})$ in adult rat islets cultured with or without GAS6 (+GAS6, $300 \mathrm{ng} / \mathrm{ml}$; -GAS6) for 96 h. (c, d) Quantification of mRNA content of Mafa and Axl by qPCR in adult rat islets treated with or without GAS6 (+GAS6, $300 \mathrm{ng} / \mathrm{ml}$; -GAS6) for $48 \mathrm{~h}$. Results are normalised to the mRNA content of $R p l 13 \alpha$. Data are shown as means \pm SEM, $n=5$. $* p<0.05$ compared with $2 \mathrm{mmol} / \mathrm{l}$ glucose within -GAS6 and +GAS6 cells in adult rat pancreas stained positive for AXL (data not shown). The mRNA content of $A x l$ was $55 \%$ lower $(p<0.05)$ in adult vs neonatal islets (Fig. 8c). The specificity of the AXL antibody was confirmed by the use of western blotting (see ESM Methods) and cortical neurons (negative control) (ESM Fig. 1).

Effect of GAS6 on adult human beta cells in vitro

Islets from five different human donors (Table 2) were included in the study to identify possible species similarities/differences considering the effects of GAS6.

GSIS and total insulin content Insulin secretion increased approximately fourfold when human islets where stimulated with $20 \mathrm{mmol} / \mathrm{l}$ glucose compared with $2 \mathrm{mmol} / \mathrm{l}$ glucose (Fig. 9a). There was no difference in GSIS between islets cultured with or without GAS6. GAS6 did not change the total insulin content of the islets (Fig. 9b).

Proliferation The level of beta cell proliferation in human donors was low compared with rat beta cells (Table 3, Figs 4, 7). GAS6 seemed to increase the proliferation of human beta cells in most donors, but this change was not statistically significant. hGH did not affect the proliferation of human beta cells.

\section{Discussion}

The time around birth is a critical window, where the beta cell mass expands and matures. Maternal malnutrition (e.g. resulting from an LP diet) can affect the outcome of this crucial period in the offspring. Here we report for the first time that GAS6 affects the proliferation and functional capacity of the perinatal beta cell. Our data reveals that Gas6, known for its mitogenic potential [19, 27], is expressed at a lower level in rat pancreases from LP offspring compared with offspring from mothers fed a normal diet. Simultaneously, a maternal LP diet increases the pancreatic mRNA content of Mafa. Interestingly, the in vitro studies in isolated islets presented here show a mitogenic effect of GAS6 on neonatal rat beta cells. This is accompanied by a negative effect of GAS6 on GSIS, which could be caused by the reduction of Mafa mRNA levels in GAS6treated neonatal rats islets. This suggests that GAS6 could be involved in perinatal regulation of the beta cell mass by stimulating proliferation of beta cells and inhibiting functional maturation.

MAFA is a master regulator of genes implicated in beta cell function, including proinsulin processing (prohormone convertase 1/3) in INS1 cells [28], glucose sensing (Slc2a2), vesicle maturation (Slc30a8), $\mathrm{Ca}^{2+}$ signalling (Camk2b) and 
Fig. 7 Effect of GAS6 on proliferation of adult rat islets. Representative sections (a) of adult rat islets cultured for $96 \mathrm{~h}$ as controls, with hGH (positive control) or with GAS6

$(300 \mathrm{ng} / \mathrm{ml})$. Islets were cultured with EdU $24 \mathrm{~h}$ before fixation and subsequently stained for PDX1. Red bar indicates $50 \mu \mathrm{m}$. (b)

Quantification of the percentage of $\mathrm{EdU}^{+} \mathrm{PDX} 1^{+}$cells (positive for EdU and PDX1). Data are shown as means \pm SEM, $n=5$ or 6. ${ }^{*} p<0.05$ compared with control
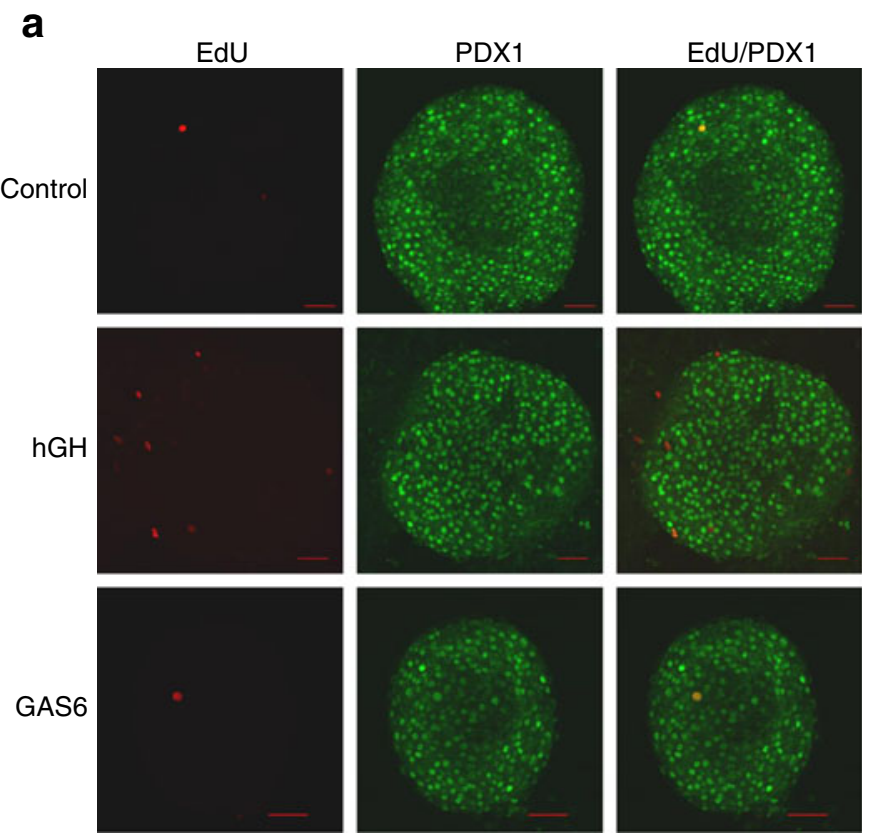

b

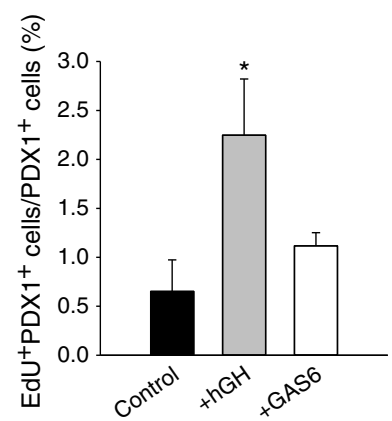

insulin secretion (Nnat) [14, 29]. Accordingly, Mafa overexpression enhances GSIS in neonatal rat beta cells [15]. In addition, MAFA induces insulin expression via binding to the insulin promoter [30]; however, total insulin content in beta cells was not affected in Mafa-deficient (-/-) mice [14], similar to the findings of the current study.

a
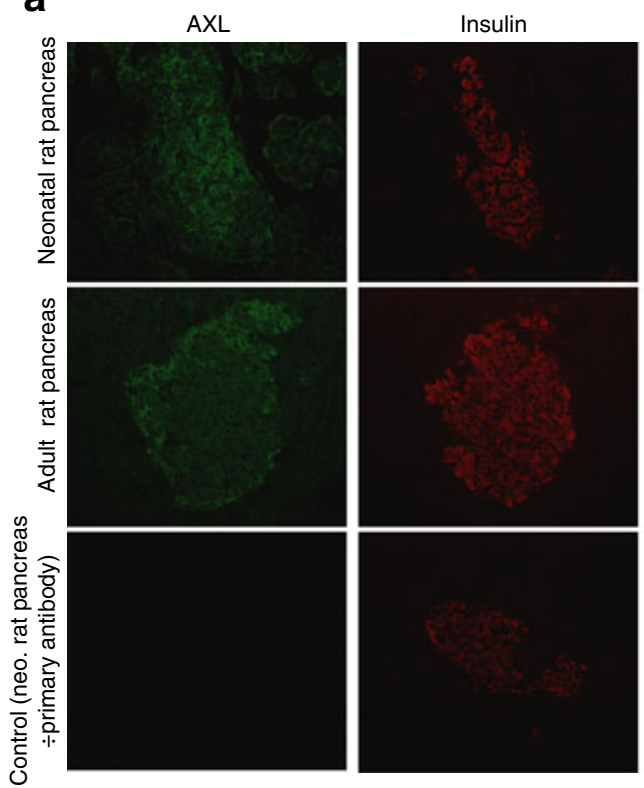

In the perinatal period, a transition from Mafb to Mafa accompanies differentiation of beta cells in a temporal way, where Mafb expression is gradually reduced as Mafa expression increases so that mature beta cells only express Mafa $[10,16]$. Interestingly, a recent study showed that Mafb was re-expressed in proliferative beta cells [31].
Fig. 8 AXL in neonatal (P2) (neo.) and adult rat pancreas (12 weeks old). (a) Representative immunohistochemical stainings of AXL (green) and insulin (red) with DAPI (blue) in pancreas from neonatal ( 2 days old) and adult (10 weeks old) Wistar rat. Yellow: cells that coexpress AXL and insulin. White bar indicates $50 \mu \mathrm{m}$. (b) Quantification of the relative enrichment of $A x l$ mRNA content in isolated b

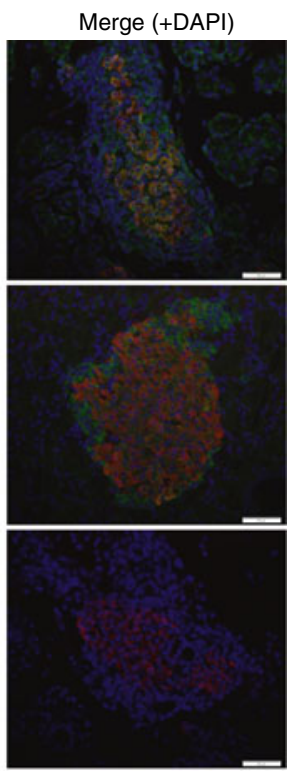

neonatal islets vs total neonatal pancreas. (c) Quantification of $A x l$ mRNA content in islets isolated from neonatal and adult rats. Results in (b) and (c) are normalised to the mRNA content of Rpl13 $\alpha$ and expressed as fold change compared to neonatal rat pancreas and neonatal rat islets, respectively. Data are shown as means \pm SEM, $n=3-5$. $* p<0.05$ compared with neonatal rat pancreas (b) or neonatal rat islets (c) 
Table 2 Basic information about the human donors

\begin{tabular}{llll}
\hline Donor no. & Sex & Age (years) & BMI $\left(\mathrm{kg} / \mathrm{m}^{2}\right)$ \\
\hline 1 & Male & 34 & 27.7 \\
2 & Female & 59 & 20.7 \\
3 & Female & 48 & 21.9 \\
4 & Female & 58 & 19.2 \\
5 & Male & 60 & 30.5 \\
\hline
\end{tabular}

Despite the GAS6-induced reduction in Mafa observed in this study, the Mafb mRNA content in GAS6-treated neonatal rat islets was unchanged.

It was recently reported that a maternal LP diet increases the levels of factors in offspring associated with mature beta cells (among others Slc2a2; a target of MAFA) [13]. Rodriguez-Trejo et al [13] suggested that the maternal LP diet changed the uterine environment to favour maturation of beta cells at the expense of proliferation. This hypothesis is supported by our finding of increased Mafa mRNA levels in LP offspring, and a similar insulin mRNA content 2 days after birth despite the reduced beta cell mass in maternal-LPdiet offspring $[5,13]$.

This study did not detect an anti-apoptotic effect of GAS6 on beta cells, in contrast to findings from studies using other cell types $[18,20]$.

GAS6 is a ligand for the AXL subfamily of receptor tyrosine kinases, comprising AXL, SKY and MER, with the highest affinity for AXL [32]. Here we show that AXL is expressed by pancreatic beta cells in rats. Interestingly, AXL was more prominent in neonatal beta cells than in adult beta cells, suggesting age-dependent differences in the level of expression of this receptor. The data presented here show that the effect of GAS6 is age dependent in rats. The reason for this could be the age-dependent difference in the expression of $A x l$ and perhaps other GAS6 receptors.
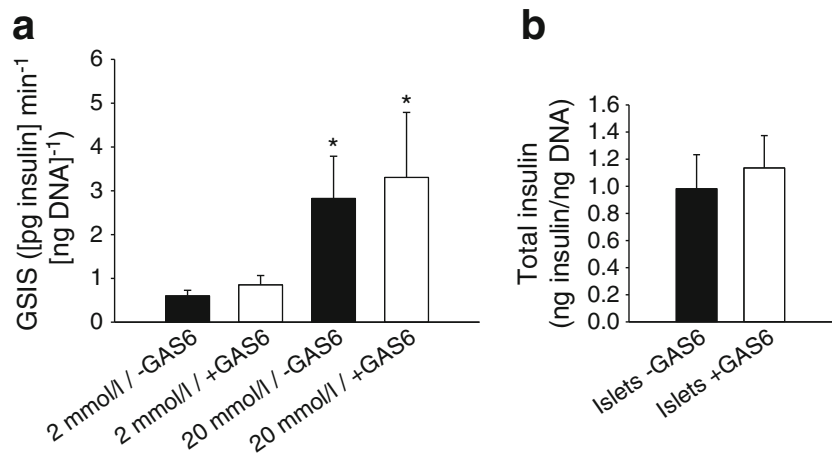

Fig. 9 GSIS and quantification of total insulin protein content in human islets cultured with or without GAS6 (+GAS6, $300 \mathrm{ng} / \mathrm{ml}$; -GAS6) for $96 \mathrm{~h}$. (a) GSIS using $2 \mathrm{mmol} / \mathrm{l}$ glucose and $20 \mathrm{mmol} / \mathrm{l}$ glucose. (b) Total insulin content. Data are shown as means \pm SEM of donors $1,2,4$ and 5
Table 3 Effect of GAS6 on proliferation of human islets

\begin{tabular}{llll}
\hline Donor no. & \multicolumn{2}{l}{$\mathrm{EdU}^{+} \mathrm{PDX} 1^{+}$cells $/ \mathrm{PDX} 1^{+}$cells $(\%)$} \\
\cline { 2 - 4 } & Control & + hGH & + GAS6 \\
\hline 1 & $0.22(901)$ & $0.41(733)$ & $0.38(1,588)$ \\
2 & $0(920)$ & $0.13(800)$ & $0.25(792)$ \\
3 & $0(1,225)$ & $0.10(987)$ & $0.17(1,168)$ \\
5 & $0.78(1,149)$ & $0.96(1,148)$ & $0.73(1,099)$ \\
\hline
\end{tabular}

Individual values from donors $1,2,3$ and 5 are shown; numbers in brackets indicate the total number of counted $\mathrm{PDX} 1^{+}$cells

Quantification of $\mathrm{EdU}^{+} \mathrm{Pdx} 1^{+}$cells of total $\mathrm{Pdx} 1^{+}$cells (\%) of human islets cultured for $96 \mathrm{~h}$ as controls, with $\mathrm{hGH}$ (positive control) or with GAS6 (300 ng/ml)

This is supported by the unchanged Mafa mRNA levels seen in GAS6-treated adult rat islets, suggesting that the reason for the absent response to GAS6 in adult rat islets lies upstream of MAFA. The lack of a negative feedback of GAS6 on the $A x l$ mRNA content in adult rat islets could also be caused by lower expression of Axl. Further studies are needed to clarify this. Adult rat islets are less responsive to mitogenic stimuli than neonatal rat islets. This is partly due to high production levels of factors associated with beta cell differentiation and inhibition of proliferation such as MAFA and P27 $[8,10]$. Thus, the lack of GAS6 effects in adult rat beta cells could be due to the abundance of such factors. Alternatively, a paracrine effect of endogen GAS6 in adult rat islets, from islet cells such as alpha cells, could blunt the effect of supplementary GAS6 [23]. It would be of great interest to investigate the effect of GAS6 in late fetal pancreas. One could speculate that GAS6 would have an even greater mitogenic effect on fetal beta cells due to the latter's immaturity.

The cell signalling pathways involved in the effects of GAS6 on neonatal rat beta cells and whether these function via AXL remain elusive. However, GAS6-induced AXL signalling in other cell types (e.g. NIH3T3 fibroblasts and 3D3 cells) is known to encompass the PI3K/AKT, PLC, Ras-regulated kinase (ERK) pathway [32-35]. It remains to be determined whether these pathways are involved in the GAS6-mediated effects observed in beta cells.

Human islets used in this study were unresponsive to GAS6. Whether beta cells from newborn/young humans are responsive to GAS6 remains to be investigated.

An interesting question to address is where GAS6 that reaches the beta cells could originate from in vivo. Since GAS6 is present in the plasma [24] it could originate from the systemic circulation. However, both pancreatic alpha cells and stellate cells synthesise and secrete GAS6 [20, 23]. Thus, GAS6 secreted from these cell types could impinge on the beta cells. 
In conclusion, we report a role for GAS6 in the regulation of function and proliferation of neonatal rat beta cells. Understanding the molecular mechanisms behind the expansion of the perinatal beta cell mass could lead to new treatment strategies for metabolic diseases such as type 2 diabetes mellitus. In addition, it may contribute to the development of in vitro-generated beta cells that could be used for transplantation.

Acknowledgements We are very grateful for the skilled technical assistance of H. Fjordvang, J. Tybjerg and L. Grønne Pedersen (Department of Biomedical Sciences, University of Copenhagen). Human islets were provided through the JDRF award 31-2008-413 (ECIT Islet for Basic Research programme to San Raffaele Diabetes Research Institute, Milan, Italy).

Funding These studies were supported by the Danish Research Council for Medical Sciences, The EU Sixth Framework programme 'Beta Cell Therapy', The Novo Nordisk Foundation and The Danish Council for Strategic Research (Grant no 09-067124 to Centre for Fetal Programming).

Duality of interest The authors declare that there is no duality of interest associated with this manuscript.

Contribution statement TNH, MR, LWG, NB and JHN conceived and designed the study. MR performed the LP study and MR and LWG the microarray study. TNH, MR and LWG carried out the qPCR for the LP study, and TNH the quantifications of the endocrine pancreas. TNH performed all in vitro experiments with neonatal and human islets. TNH, CAMJ and CKP designed and performed the in vitro studies using adult rat islets. TNH drafted the manuscript and all authors contributed to analysis and interpretation of the data as well as critical revision of the manuscript. All authors approved the final version of the manuscript.

\section{References}

1. Hales CN, Barker DJ, Clark PM et al (1991) Fetal and infant growth and impaired glucose tolerance at age 64. BMJ 303:1019-1022

2. Hales CN, Barker DJ (1992) Type 2 (non-insulin-dependent) diabetes mellitus: the thrifty phenotype hypothesis. Diabetologia 35:595-601

3. Brons C, Jacobsen S, Hiscock N et al (2012) Effects of high-fat overfeeding on mitochondrial function, glucose and fat metabolism, and adipokine levels in low-birth-weight subjects. Am J Physiol Endocrinol Metab 302:E43-E51

4. Barker DJ, Osmond C, Kajantie E, Eriksson JG (2009) Growth and chronic disease: findings in the Helsinki Birth Cohort. Ann Hum Biol 36:445-458

5. Reusens B, Theys N, Dumortier O, Goosse K, Remacle C (2011) Maternal malnutrition programs the endocrine pancreas in progeny. Am J Clin Nutr 94:1824S-1829S

6. Matveyenko AV, Butler PC (2008) Relationship between beta-cell mass and diabetes onset. Diabetes Obes Metabol 10(suppl 4):2331

7. Aguayo-Mazzucato C, Sanchez-Soto C, Godinez-Puig V, Gutierrez-Ospina G, Hiriart M (2006) Restructuring of pancreatic islets and insulin secretion in a postnatal critical window. PLoS One 1:e35
8. Lee YC, Nielsen JH (2009) Regulation of beta cell replication. Mol Cell Endocrinol 297:18-27

9. Kaung HL (1994) Growth dynamics of pancreatic islet cell populations during fetal and neonatal development of the rat. Dev Dyn 200:163-175

10. Nishimura W, Kondo T, Salameh T et al (2006) A switch from MafB to MafA expression accompanies differentiation to pancreatic beta-cells. Dev Biol 293:526-539

11. Petrik J, Reusens B, Arany E et al (1999) A low protein diet alters the balance of islet cell replication and apoptosis in the fetal and neonatal rat and is associated with a reduced pancreatic expression of insulin-like growth factor-II. Endocrinology 140:4861-4873

12. Dumortier O, Blondeau B, Duvillie B, Reusens B, Breant B, Remacle C (2007) Different mechanisms operating during different critical time-windows reduce rat fetal beta cell mass due to a maternal low-protein or low-energy diet. Diabetologia 50:24952503

13. Rodriguez-Trejo A, Ortiz-Lopez MG, Zambrano E et al (2012) Developmental programming of neonatal pancreatic beta-cells by a maternal low protein diet in rats involves a switch from proliferation to differentiation. Am J Physiol Endocrinol Metab 302:14311439

14. Zhang C, Moriguchi T, Kajihara M et al (2005) MafA is a key regulator of glucose-stimulated insulin secretion. Mol Cell Biol 25:4969-4976

15. Aguayo-Mazzucato C, Koh A, El Khattabi I et al (2011) Mafa expression enhances glucose-responsive insulin secretion in neonatal rat beta cells. Diabetologia 54:583-593

16. Artner I, Hang Y, Mazur M et al (2010) MafA and MafB regulate genes critical to beta-cells in a unique temporal manner. Diabetes 59:2530-2539

17. Hafizi S, Dahlback B (2006) Gas6 and protein S. Vitamin Kdependent ligands for the Axl receptor tyrosine kinase subfamily. FEBS J 273:5231-5244

18. Goruppi S, Ruaro E, Schneider C (1996) Gas6, the ligand of Axl tyrosine kinase receptor, has mitogenic and survival activities for serum starved NIH3T3 fibroblasts. Oncogene 12:471-480

19. Stenhoff J, Dahlback B, Hafizi S (2004) Vitamin K-dependent Gas6 activates ERK kinase and stimulates growth of cardiac fibroblasts. Biochem Biophys Res Commun 319:871-878

20. Lafdil F, Chobert MN, Couchie D et al (2006) Induction of Gas6 protein in CCl4-induced rat liver injury and anti-apoptotic effect on hepatic stellate cells. Hepatology 44:228-239

21. Lafdil F, Chobert MN, Deveaux V et al (2009) Growth arrestspecific protein 6 deficiency impairs liver tissue repair after acute toxic hepatitis in mice. J Hepatol 51:55-66

22. Kulman JD, Harris JE, Xie L, Davie EW (2001) Identification of two novel transmembrane gamma-carboxyglutamic acid proteins expressed broadly in fetal and adult tissues. Proc Natl Acad Sci U S A 98:1370-1375

23. Stenberg LM, Nilsson E, Ljungberg O, Stenflo J, Brown MA (2001) Synthesis of gamma-carboxylated polypeptides by alphacells of the pancreatic islets. Biochem Biophys Res Commun 283:454-459

24. Hung YJ, Lee CH, Chu NF, Shieh YS (2010) Plasma protein growth arrest-specific 6 levels are associated with altered glucose tolerance, inflammation, and endothelial dysfunction. Diabetes Care 33:1840-1844

25. Augustine KA, Rossi RM, Van G et al (1999) Noninsulindependent diabetes mellitus occurs in mice ectopically expressing the human Axl tyrosine kinase receptor. J Cell Physiol 181:433447

26. Brunstedt J (1980) Rapid isolation of functionally intact pancreatic islets from mice and rats by percollTM gradient centrifucation. Diabetes Metabol 6:87-89 
27. Sainaghi PP, Castello L, Bergamasco L, Galletti M, Bellosta P, Avanzi GC (2005) Gas6 induces proliferation in prostate carcinoma cell lines expressing the Axl receptor. J Cell Physiol 204:36-44

28. Wang H, Brun T, Kataoka K, Sharma AJ, Wollheim CB (2007) MAFA controls genes implicated in insulin biosynthesis and secretion. Diabetologia 50:348-358

29. Hang Y, Stein R (2011) MafA and MafB activity in pancreatic beta cells. Trends Endocrinol Metabol 22:364-373

30. Zhao L, Guo M, Matsuoka TA et al (2005) The islet beta cellenriched MafA activator is a key regulator of insulin gene transcription. J Biol Chem 280:11887-11894

31. Lu J, Hamze Z, Bonnavion R et al (2012) Reexpression of oncoprotein MafB in proliferative beta-cells and Men1 insulinomas in mouse. Oncogene 31:3647-3654
32. Hafizi S, Dahlback B (2006) Signalling and functional diversity within the Axl subfamily of receptor tyrosine kinases. Cytokine Growth Factor Rev 17:295-304

33. Fridell YW, Jin Y, Quilliam LA et al (1996) Differential activation of the Ras/extracellular-signal-regulated protein kinase pathway is responsible for the biological consequences induced by the Axl receptor tyrosine kinase. Mol Cell Biol 16:135-145

34. Goruppi S, Ruaro E, Varnum B, Schneider C (1997) Requirement of phosphatidylinositol 3-kinase-dependent pathway and Src for Gas6-Axl mitogenic and survival activities in NIH 3 T3 fibroblasts. Mol Cell Biol 17:4442-4453

35. Korshunov VA (2012) Axl-dependent signalling: a clinical update. Clin Sci (Lond) 122:361-368 